\title{
The Effect of Micro and Small Business (Mses) Performance on Inclusive Growth in Indonesia: Panel Dynamic Simultaneous Equation Model
}

\author{
Agustina Suparyati ${ }^{1}$, Sutyastie S.Remi ${ }^{2}$, Kodrat Wibowo ${ }^{3}$, Bagja Muljarijadi ${ }^{4}$ \\ \{agustina_suparyati@trisakti.ac.id'1, tatiremi@gmail.com², kodrat_w@hotmail.com³, \\ bagdja@fe.unpad.ac.ic ${ }^{4}$ \} \\ Economic and Business Faculty of Trisakti University ${ }^{1}$, Economic and Business Faculty of \\ Padjajaran University $2,3,4$
}

\begin{abstract}
The purpose of this research is to analyze the role of MSEs in driving economic growth to realize inclusive growth, therefore the thinking flow in this study divides the analysis stage into 3 blocks of equation: the MSEs performance equation block, the economic growth block and the inclusive growth equation block. In this study used a panel dynamic simultaneous equation model for 33 provinces in Indonesia from 2010 to 2019 using the Generalized Method of Moments Arellano-Bond (GMM A-B) estimation method. The MSEs Performance Block analyzed using the Stucture-ConductPerformance (SCP) approach shows that there is a simultaneousity relationship between the MSEs market structure, corporate behavior and MSEs performance as well as a significant influence on variable inflation, wages, government regulation of MSEs and infrastructure indices on MSEs performance as measured by internal efficiency in Indonesia. The Economic Growth Equation Bloc refers to J.Shumpeter's growth theory which places enterprenership and innovation as the main factors influencing economic growth and the regression results show that the performance of MSEs has a significant effect on economic growth. The final stage of this study is analyzing the inclusive growth equation bloc which shows that economic growth supported by the performance of MSEs is able to increase labor absorption as well as reduce income distribution inequation but has not been able to lower the poverty level in other words that inclusive growth goals to lower poverty levels have not materialized in Indonesia.
\end{abstract}

Keywords: Inclusive Growth; Poverty; Micro and Small Enterprises; Inequation; Labor Absorption

\section{Introduction}

Inclusive growth is growth that is pro-poor by empowering the poor to actively participate and significantly benefit from economic activities [1], [2]. Inclusive growth has two characteristics, namely process and result. The first focus is through a process where inclusive 
economic growth is growth that extends across sectors or is labor intensive, so that inclusive growth can be said to be growth that involves the participation of all parties without discrimination and is able to involve all economic sectors. The second focus is on the outcomes of the growth process. In this case, the concept of inclusive growth is closely related to the concept of pro-poor growth. In other words, based on the results achieved, inclusive growth is economic growth that is able to reduce the population for groups who are not benefited from the economy, namely the poor [3].

The development paradigm that is in accordance with the characteristics of inclusive growth that is participatory and pro-poor can be implemented through community empowerment strategies. The concept of community empowerment is a concept of economic development that encapsulates social values that reflect a new paradigm that is peoplecentered, participatory, empowering and sustainable [4]. One form of community empowerment that is in accordance with the character of inclusive growth, namely participatory and pro-poor is Micro and Small Enterprises (MSEs) which play an important role in economic and social development because historical experience shows MSEs were able to survive the Indonesian economic crisis in 1997. This argument It is also strengthened because most of Indonesia's population has low education, so doing business in the MSEs sector is the right choice, where education is not an absolute requirement in doing business in the MSEs sector and living in micro and small business activities both in the traditional and modern sectors, and is able to absorb a lot of labor.

The importance of the role of MSEs in the economy can mainly be seen from the large contribution of MSEs to the absorption of the national workforce. In Indonesia, based on data from the Ministry of Cooperatives and MSMEs, it shows that in 2017 the largest employment absorption was carried out in Micro and Small Enterprises (UMK) which were able to absorb 112.93 million workers or 93.91 percent of the total workforce. The role of MSEs as a driver of economic growth can also be developed through industrial agglomeration. The growth and development of micro and small business activities ideally refers to economic agglomeration or industrial agglomeration which can become a vortex of economic growth so that MSE activities accompany the existing population agglomeration. The emergence of growth poles then triggers a spillover effect, namely externalities resulting from the agglomeration formed from several industrial groups. The advantage of agglomeration for MSEs is to take advantage of population concentration by having as many variants of economic activities as possible within the adjacent community, thereby saving transportation costs and saving other costs which are often referred to as industrial clusters. An agglomeration is nothing more than a collection of industrial clusters of economic activity from the population. Agglomeration is an external efficiency that will have a positive impact on the development of MSEs. The modern theory of MSMEs, namely flexible specialization (FS) emphasizes the importance of subcontracting networks and the advantages of agglomeration through the formation of industrial clusters for the development of MSEs [5].

In the theory of economic growth from Joseph Schumpeter explains that economic growth will occur if there is innovation from the entrepreneur, where innovation is the application of new knowledge and technology in the business world. Innovation acts as a source of competitive advantage obtained through $R \& D$ [6]. Innovation for developing countries is very important because it relates to the sustainability of MSEs which have a major contribution to employment, however, implementing innovative ideas in MSEs requires strong decisions and resources to make it happen. A number of other studies argue that MSEs, apart from being an engine for innovation, economic growth and employment, also increase social mobility. The jobs created and offered by MSEs generally increase the welfare, standard of living, income 
level, and social stability of people around the world, both in developing and developed countries. The existence of MSEs increases competition and entrepreneurship so that it has external benefits on efficiency, innovation and the level of economic productivity [7]-[9]. In Indonesia, MSEs have an important role as a policy instrument to reduce poverty through their role as the largest creator of job opportunities or income redistribution policies, so it is not surprising that since the beginning of the New Order period until now, many efforts have been made to support the development of MSEs in various forms. programs and policies, including the issuance of Law Number 20 of 2008 concerning MSEs [10].

In the theory of economic growth from Joseph Schumpeter explains that economic growth will occur if there is innovation from the entrepreneur, where innovation is the application of new knowledge and technology in the business world [6]. Innovation acts as a source of competitive advantage obtained through R\&D. Innovation for developing countries is very important because it relates to the sustainability of MSEs which have a major contribution to employment, however, implementing innovative ideas in MSEs requires strong decisions and resources to make it happen. According to Schumpeter, MSEs play an important role in revolutionizing the industrial sector for sustainability, replacing old innovations that can be done through creative destruction. [11].

In an effort to achieve inclusive economic growth, the position of MSEs in the eyes of the government is very important, so it is hoped that the existence of Indonesian MSEs has a healthy performance in the sense of being innovative, productive, efficient and absorbing a lot of workers so that they can become a driver of economic growth to realize inclusive growth that demands the existence of economic growth conditions that are able to reduce poverty and inequality in income distribution and increase employment, so the purpose of this research is to estimate the role of Micro and Small Enterprises in encouraging economic growth to achieve inclusive growth in Indonesia. In this study, the equation model used is a dynamic panel simultaneous equation model with the Generalized Method of Moment Arellano-Bond (GMM-AB) estimation method. The framework of thinking in this study can be seen in Figure1.

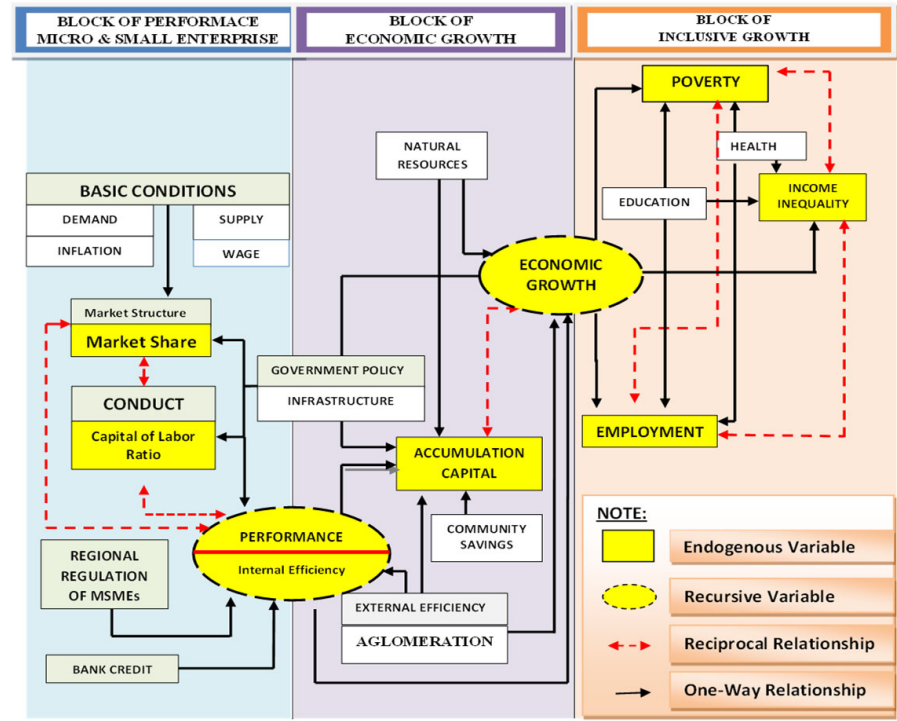

Fig. 1. Conceptual Framework of MSEs Performance Impact on Inclusive Growth 


\section{Methodology Research}

\subsection{Data source}

The data source used is secondary data from BPS Indonesia in 2010-2019 covering 33 provinces. Micro and Small Business data is proxied with Micro and Small Industry data published by BPS.

\subsection{Regression Estimation of the Simultaneous Panel of Dynamic using the Generalized Method of Moment Arellano-Bond (GMM A-B)}

Simultaneous panel dynamic estimation using the GMM AB method is able to overcome endogeneity problems related to the use of instrument variables, namely the dependent variable lag if using the orthogonality condition that exists between the lag values of yit and vit disturbances, so that without a regressor, the equation can be written: yit $=$.yt- $1+$ vit for $\mathrm{i}$ $=1,2, \ldots, \mathrm{N}$; and $\mathrm{t}=1,2,3, \ldots, \mathrm{N}$. (Amba Oyon, Claude Marius and Mbratana ,2018). The A-B GMM estimation method produces unbiased, consistent and efficient estimates. The following is the estimation result of GMM A-B one step estimator. The A-B GMM estimation method produces unbiased, consistent and efficient estimates. The following is the estimation result of GMM A-B one step estimator.

$$
\begin{aligned}
\left(\begin{array}{l}
\widehat{\delta} \\
\widehat{\beta}
\end{array}\right)=[ & \left(N^{-1} \sum_{i=1}^{N}(\Delta y i, t-1, \Delta x i)^{\prime} Z i\right) \widehat{W}\left(N^{-1} \sum_{i=1}^{N} Z i^{\prime}(\Delta y i, t-1, \Delta Z i)\right]^{-1} \\
& {\left[\left(N^{-1} \sum_{i=1}^{N}(\Delta y i, t-1, \Delta x i)^{\prime} Z i\right) \widehat{W}\left(N^{-1} \sum_{i=1}^{N} Z i^{\prime} \Delta y i\right)\right] }
\end{aligned}
$$

Note :

$\mathrm{Zi}$ : Valid instrument matrix

$W$ : Unbiased and consistent estimate for $\mathrm{W}(\mathrm{LxL})$ where $\mathrm{L}$ is the number of instrument variables

To get the results of the two-step estimator estimation by substituting the weights $\widehat{W}$ dengan $\hat{\wedge}^{-1}$, with :

$$
\hat{\wedge}^{-1}=\mathrm{N}^{-1} \sum_{i=1}^{N} Z i^{\prime} \Delta v i . \Delta v i . Z i
$$

So that the estimation results of GMM Arellano-Bond are as follows:

$$
\begin{aligned}
\left(\begin{array}{c}
\widehat{\delta} \\
\widehat{\beta}
\end{array}\right)= & {\left[\left(N^{-1} \sum_{i=1}^{N}(\Delta y i, t-1, \Delta x i)^{\prime} Z i\right) \hat{\wedge}^{-1}\left(N^{-1} \sum_{i=1}^{N} Z i^{\prime}(\Delta y i, t-1, \Delta X i)\right]^{-1}\right.} \\
& {\left[\left(N^{-1} \sum_{i=1}^{N}(\Delta y i, t-1, \Delta x i)^{\prime} Z i\right) \hat{\wedge}^{-1}\left(N^{-1} \sum_{i=1}^{N} Z i^{\prime} \Delta y i\right)\right] }
\end{aligned}
$$

\subsection{Parameter Significance Test}

Parameter significance testing is used to determine whether there is a relationship in the model. In the dynamic panel model to determine whether there is a relationship in the model, two methods can be used, namely the Wald test and the simultaneity test. 


\subsection{Model Specification Test}

The model specification test used is the Arellano-Bond test (consistency test) and Sargan test (instrument validity test).

\subsection{Arellano-Bond . Test}

The Arellano-Bond test is used to test the consistency of the estimates obtained from the GMM process. The Arellano-Bond test hypotheses are as follows:

Ho: There is no autocorrelation in the remainder of the $\mathrm{i}$-th first difference order $\mathrm{Hi}$ : There is an autocorrelation in the remainder of the i-th first difference order

$$
\begin{aligned}
& \boldsymbol{m}(\mathbf{2})=\frac{\Delta \widehat{v} i, t-2 \Delta \widehat{v}}{(\Delta \widehat{v}) \mathbf{1} / \mathbf{2}} \\
& \qquad \widehat{\widehat{v}^{\prime}} \mathrm{i}, \mathrm{t}-2: \text { Vektor error in 2nd lag with order } \mathrm{q}=\sum_{\mathrm{i}=1}^{\mathrm{N}} \mathrm{Ti}-4
\end{aligned}
$$

$\Delta \widehat{v}:$ Vektor error vector truncated to fit $\Delta \widehat{v}^{\prime} i, t-2$ of size q $x 1$, the decision is that Ho is

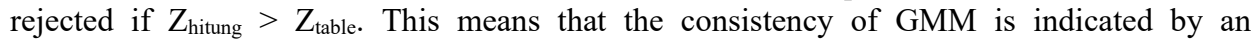
insignificant statistical value (failed to reject $\mathrm{Ho}$ ) on $\mathrm{m}_{2}$.

\subsection{Sargan Test}

Sargan test is used to determine the validity of the use of instrument variables whose number exceeds the estimated number of parameters (overidentifying restriction condition). The Sargan test hypothesis is as follows:

Ho: The condition of overidentifying restriction in model estimation is valid $\mathrm{Hi}$ : The condition of overidentifying restriction in model estimation is invalid

$S=\widehat{v}^{\prime} Z\left[\sum_{i=1}^{N} Z^{\prime} i \widehat{v} 1 . \widehat{v} 1 Z i\right]^{-1} Z^{\prime} \hat{v} \sim X_{L-(k+1)}^{2}$

Note :

Vิ: Model Estimation Error

The decision is that Ho is rejected if the statistical value of the $\mathrm{S}$ test is greater than the chi-square table $\left(\chi^{2}\right)$ or the $p$-value $<\alpha$.

\subsection{Model specifications and measurements}

The method used in this study is the simultaneous equation of dynamic panel data with the consideration that in this study there are many economic variables that are simultaneous and dynamic, meaning that the value of a variable is influenced by the value of other variables and also the value of the relevant variable in the past. The simultaneous equation regression of dynamic panel data in this study uses the analysis method of the Generalized Method of Moment Arellano-Bond (GMM A-B) approach. The advantage of this method is that it can determine the short-term and long-term effects. The model specifications in each equation block are built based on theory and empirical studies as follows: 


\section{a) The MSEs Performance Equation Block}

The Performance Block for Micro and Small Enterprises (MSEs) is compiled using Structural-Conduct-Performance (SCP) analysis which consists of 3 structural equations, namely:

Market Structure Equation of MSEs (MS)

MSit $=\alpha_{0}+\alpha_{1} \cdot$ MSi $_{\mathrm{t}-1}+\alpha_{2}$.INFit $+\alpha_{3}$. WAGEit $+\alpha_{4}$.INFRit $+\alpha_{5}$.CLRit $+\alpha_{6}$. X-Effit $+\varepsilon_{\text {it }}$

Hyphotesis : $\alpha_{1}, \alpha_{2} \alpha_{3} \alpha_{4} \alpha_{5}$ dan $\alpha_{6}>0$

Conduct Equation of MSEs (CRL):

CLRit $=\beta_{0}+\beta_{1}$. CLRi $\mathrm{CL}_{\mathrm{t}-1}+\beta_{2}$. INFRit $+\beta_{3}$. MSit $+\beta_{4}$. X-Effit $+\varepsilon_{\text {it }}$

Hyphotesis: $\beta_{1}, \beta_{2}, \beta_{3}, \beta_{4}>0$

Performance Equation of MSEs (X-Eff):

$\mathrm{X}$-Effit $=\delta_{0}+\delta_{1}$. X-Effi $\mathrm{t}_{\mathrm{t}-1}+\delta_{2}$. INFRit $+\delta_{3}$. REGit $+\delta_{4}$. AGLOit $+\delta_{5}$. CREDITit $+\delta_{6}$. MSit + $\delta_{7}$. CLRit $+\varepsilon_{\text {it }}$

Hyphotesis: $\delta_{1}, \delta_{2}, \delta_{3}, \delta_{4}, \delta_{5}, \delta_{6}$, dan $\delta_{7}>0$

Table 1. Definition Variable of used in The MSEs Performance Equation Block

\begin{tabular}{ll} 
Variable & \multicolumn{1}{c}{\begin{tabular}{c} 
Definition Variable \\
\hline MS
\end{tabular}} \\
$\qquad \begin{array}{l}\text { The Formula of Market Share is : } \\
\text { CLR }\end{array}$ & $\begin{array}{l}\text { CLR Capital Labor Ratio is used as a variable to measure company behavior with the } \\
\text { formula: }\end{array}$ \\
& The greater the CLR value indicates that the production technology used is more \\
& capital intensive
\end{tabular}

Note: 
$x$ value of certain variables in the $i$-th province in the $j$ year

$\mathrm{Xij}=$ the value of a certain variable in the $\mathrm{i}$-th province in the $\mathrm{j}$ year

$\mathrm{X}_{\operatorname{maxj}}=$ maximum value for certain variables in certain provinces in year $\mathrm{j}$

Infrastructure Index is a composite index of:

Road Infrastructure as measured by the Road Display of each province $(\mathrm{Km})$

Electricity infrastructure measured Number of Electricity Customers (persons)

Information and Communication Engineering Infrastructure as measured by the Percentage of the population who owns/masters Cellular Phones by Province (persons)

Then each Xij index will be multiplied by the weight obtained from the Principle Component Analysis (PCA) analysis tool, so that the magnitude of the Infrastructure indicator

$\mathrm{INFR}=\Sigma \mathrm{Xij} x$ bobot

\begin{tabular}{|c|c|}
\hline REG & $\begin{array}{l}\text { Number of regional regulations on MSMEs produced by districts/cities in each } \\
\text { province to the national total }\end{array}$ \\
\hline CREDIT & $\begin{array}{l}\text { Contribution of Micro and Small Business Loans by Commercial Banks to total credit } \\
\text { per province relative to total national MSE credit }\end{array}$ \\
\hline AGLO & $\begin{array}{l}\text { Variable to measure the level of external efficiency is indicated by the level of } \\
\text { agglomeration which is calculated by the formula in the Balassa index as follows: } \\
\qquad \text { Ballasa Index }=\frac{\left(\frac{\sum i j}{\sum j E i j}\right)}{\frac{\sum i E i j}{\sum i \sum j E i j}} \\
\text { Note : } \mathrm{i}=\text { Sector } ; \mathrm{j}=\text { Region and } \mathrm{E}=\text { Labor. The numerator of this index represents } \\
\text { the regional share of the total workforce in MSEs. The more centralized an industry } \\
\text { is, the greater its Reply index. Agglomeration is said to be strong if the ballast index } \\
\text { number is above } 4 \text {, average or moderate if the value is between } 2 \text { and } 4 \text {, weak if the } \\
\text { value is between } 1 \text { to } 2 \text {, while a value of } 0 \text { to one means that there is no agglomeration } \\
\text { or the area does not have a comparative advantage for agglomeration to occur. }\end{array}$ \\
\hline
\end{tabular}

The end of the flow chart in the MSEs performance block will produce MSE performance equation (X-Eff) which in the next block (Economic Growth Equation Block) will be a recursive variable that represents MSE performance in the next step.

\section{b) Economic Growth Equation Block}

The Economic Growth Equation Block is compiled based on Schumpeter's theory of economic growth emphasizing that the economic progress of a society is not only influenced by the accumulation of capital, labor and natural resources, it is also supported by innovation by entrepreneurs, and economic progress is defined as an increase in the total output of the community [12]. Based on the theory and empirical studies, the equation model in the block of economic growth is compiled with a simultaneous equation model as follows:

Capital Accumulation Equation (INV)

$\mathrm{INVit}=\beta_{0}+\beta_{1} . \mathrm{INVi}_{\mathrm{t}-1}+\beta_{2}$ INFRit $+\beta_{3} . X \widehat{-E f} f t t+\beta_{4}$. AGLOit $+\beta_{5}$ NRit $+\beta_{6}$. SAVEit

$+\beta_{6}$. GROWTHit $+\varepsilon_{4}$

Hyphotesis: $\beta_{1}, \beta_{2}, \beta_{3}, \beta_{4}, \beta_{5}$, dan $\beta_{6},>0$

Economic Growth Equation (GROWTH) 
GROWTHit $=\mu_{0}+\mu_{1}$. GROWTHi $t_{t-1}+\mu_{2} . . X \widehat{-E f} f \imath t+\mu_{3}$. AGLOit $+\mu_{4}$. INFRit $+\mu_{5}$. NRit + $\mu_{6}$. INVit $++\varepsilon_{6}$

Hyphotesis: $\mu_{1}, \mu_{2}, \mu_{3}, \mu_{4}, \mu_{5}$, dan $\mu_{6}>0$

Table 2. Definitions of Variables Used in Economic Growth Block Equation

\begin{tabular}{cl}
\hline Variable & \multicolumn{1}{c}{ Definition Variable } \\
\hline$X \widehat{-E f f}$ & $\begin{array}{l}\text { Efficiency Internal fitted is the estimation result of the MSEs performance equation } \\
\text { which has been influenced by the variables in the MSEs performance equation block. }\end{array}$ \\
INV & $\begin{array}{l}\text { Share of Gross Fixed Investment (PMTB) to GRDP per province } \\
\text { Share of Public Savings per province to national savings is measured by the amount } \\
\text { of public savings in Commercial Banks and Rural Banks by Province }\end{array}$ \\
NR & $\begin{array}{l}\text { Natural Resources as measured by the contribution of the agriculture, forestry and } \\
\text { mining sectors to GRDP }\end{array}$ \\
EROWTH & Economic growth rate as measured by per capita GRDP growth
\end{tabular}

\section{c) Inclusive Growth Equation Block}

The inclusive Growth Equation Block is structured to prove that economic growth that has been influenced by the performance of the MSEs (recursive growth equation) can increase employment, reduce inequality in income distribution and poverty levels.

Income Distribution Inequality Equation

$\mathrm{INEQit}=\beta_{0}+\beta_{1} \cdot \mathrm{INEQi}_{\mathrm{t}-1}+\beta_{2}$. GR $\widehat{\mathrm{OWT}} \mathrm{H} \iota t+\beta_{3}$. EDUit $+\beta_{4}$ HEALTHit $+\beta_{5}$.POVit $+\beta_{6}$.

EMPLit ${ }_{+}+\varepsilon_{8}$

Hyphotesis: $\beta_{1}, \beta_{2}, \beta_{3} \beta_{4}, \beta_{6}<0$ dan $\beta_{5}>0$

Poverty Equation

POVit $=\delta_{0}+\delta_{1}$. POVit-1 $+\delta_{2}$ GR $\widehat{O W T H}$ t $t+.+\delta_{3}$.EDUit $+\delta_{4}$.HEALTHit $+\delta_{5}$.INEQit + $\delta_{6}$.EMPLit $+\varepsilon_{9}$

Hyphotesis : $\delta_{1}, \delta_{2}, \delta_{3}, \delta_{4}, \delta_{6}<0$ dan $\delta_{5}>0$

Employment Equation

EMPLit $=\mu_{0}+\mu_{1}$. EMPLi $_{\mathrm{t}-1}+\mu_{2}$. GROWT $H+\mu_{3}$.INEQit $+\mu_{4}$.POVit $+\mu_{5}$. EDUit + $\mu_{6 .}$ HEALTHit $+\mu_{6 .}+\varepsilon_{10}$

Hiphotesis: $\mu_{1}, \mu_{2}, \mu_{4}, \mu_{5}, \mu_{6}>0$ dan $\mu_{3,} \mu_{4},<0$

Table 3. Definition Variables of Use in The Inclusive Growth Block Equation

\begin{tabular}{|c|c|}
\hline Variable & Variable Definition \\
\hline GROWTH & $\begin{array}{l}\text { Fitted Economic Growth which is the result of estimation using } \\
\text { recursive regression equation }\end{array}$ \\
\hline INEQ & Inequality of Income Distribution as measured by the Gini Ratio \\
\hline POV & Percentage of poor people \\
\hline EMPL & Labor absorption as measured by ( 1 - unemployment rate (percent) $)$ \\
\hline EDU & Average length of school \\
\hline HEALTH & Number of households with proper sanitation \\
\hline
\end{tabular}

\section{Result and Discussion}




\subsection{MSEs Performance Equation Block}

The results of processing using the GMM-AB method for the MSE performance equation block consisting of 3 (three) structural equations, namely the Market Share (MS) structural equation, MSEs behavior (CLR) and MSEs performance (X-Eff). parameter estimation with GMM Arellano-Bond has met the estimator consistency criteria shown by the Arellano-Bond test results $(\mathrm{AB}$ test) with statistical value and probability value ( $\mathrm{p}$-value) greater than $\alpha=5 \%$ then Ho is accepted which concludes that in the three equations each structural equation, namely market share (MS), MSEs behavior (CLR) and MSEs performance (X-Eff) there is no autocorrelation, meaning that there is no correlation between the error in the current period $(\mathrm{t})$ and the error. the previous period (t-1) in the three structural equations. After testing the significance of the parameters, the next step is to measure the criteria for the best model. The dynamic panel method with the Arellano-Bond GMM approach can be said to be good if it meets the criteria for consistency and instrument validity. Testing the best model criteria using the Arellano-Bond GMM approach explains that the MS, CLR and X-Eff structural equations have met the estimator consistency criteria shown by the Arellano-Bond test results (AB test) on $\mathrm{m} 2$ showing a p-value greater than $\alpha=5 \%$ then Ho is accepted which concludes that in the three structural equations there is no autocorrelation in the second-order first difference error or in other words there is no correlation between the error in the current period ( $t$ ) and the error in the previous period $(\mathrm{t}-1)$.

The estimation results in the MSE performance equation block consisting of 3 equations, namely the Market Share (MS) equation, MSE Behavior (CLR) and MSEs Performance (XEff show the results that the market share equation regression (MSt-1) and MSE performance (X-Efft-1) has a negative direction, meaning that in the future the MSEs market share and MSEs performance between provinces will converge or tend to be more evenly distributed, but CLRt-1 has a positive direction on company behavior, which means that in the future the MSE production pattern will be tend to be capital-intensive. MS, CLR and X-Eff are proven to have a significant simultaneous relationship.

Table 4. Estimation Results of MSEs Performance Equation Block Using the GMM A-B Method

\begin{tabular}{|c|c|c|c|c|c|c|c|c|c|}
\hline \multirow{2}{*}{ Yariabel } & \multicolumn{3}{|c|}{$\begin{array}{l}\text { Market Share } \\
\text { (MS) }\end{array}$} & \multicolumn{3}{|c|}{$\begin{array}{c}\text { Capital Labor to Ratio } \\
\text { (CLR) }\end{array}$} & \multicolumn{3}{|c|}{$\begin{array}{c}\text { Internal Efficienci } \\
(\boldsymbol{X} \text {-Eff }) \\
\end{array}$} \\
\hline & $\begin{array}{l}\text { Estimated } \\
\text { Coefficiens }\end{array}$ & P-Value & $\begin{array}{l}\text { Long-nun } \\
\text { Multiplier } \\
\end{array}$ & \begin{tabular}{l|} 
Estimated \\
Coefficients
\end{tabular} & P-Value & $\begin{array}{l}\text { Long-nun } \\
\text { Mulniplier }\end{array}$ & $\begin{array}{l}\text { Estimated } \\
\text { Coefficiens }\end{array}$ & P-Value & $\begin{array}{l}\text { Long-nan } \\
\text { Multiplier } \\
\end{array}$ \\
\hline MSt-1 & -0.406909 & 0.000 & & & & & & & \\
\hline CLRt-1 & & & & 0.0870389 & 0.000 & & & & \\
\hline X-Efft-1 & & & & & & & -0.13748 & 0.000 & \\
\hline INFt & -0.037690 & 0.000 & $-0,02667$ & & & & & & \\
\hline WAGEt & 0.016803 & 0.000 & 0,01194 & & & & & & \\
\hline INFRt & -0.007969 & 0.000 & $-0,00566$ & 0.3079684 & 0.000 & 0,337329 & 3.229625 & 0.000 & 2,83926 \\
\hline REGt & & & & & & & 2.293809 & 0.000 & 2,01655 \\
\hline AGLOt & & & & & & & 28.03363 & 0.000 & 24,64521 \\
\hline CREDITt & & & & & & & -0.20490 & 0.886 & $-0,18013$ \\
\hline MSt & & & & 0.399940 & 0.000 & 0,438069 & 8.77391 & 0.000 & 7,71341 \\
\hline CLRt & 0.327192 & 0.000 & 0,23256 & & & & -28.6793 & 0.000 & $-25,21285$ \\
\hline X-Efft & -0.022978 & 0.000 & $-0,01633$ & -0.215266 & 0.000 & $-0,235788$ & & & \\
\hline Constata & 5.556 & 0.000 & & 9.178074 & 0.000 & & 34.66786 & 0.000 & \\
\hline \multirow{2}{*}{$\begin{array}{l}\text { Arellano- } \\
\text { Bond } m 2\end{array}$} & $Z$ & P-Value & Keputusan & $Z$ & P-Value & Keputusan & $Z$ & P-Value & Keputusan \\
\hline & -1.3553 & 0.1753 & $\begin{array}{c}\text { No } \\
\text { Autocorrelation }\end{array}$ & 1.198 & 0.2309 & $\begin{array}{c}\text { No } \\
\text { Autocorrelation }\end{array}$ & -2.2958 & 0.0917 & $\begin{array}{c}\text { No } \\
\text { Autocorrelation }\end{array}$ \\
\hline \multirow{2}{*}{$\begin{array}{l}\text { Sargan } \\
\text { Test }\end{array}$} & Chi (27) & P-Value & Keputusan & Chi (27) & P-Value & Keputusan & Chi (27) & P-Value & Keputusan \\
\hline & 28.14596 & 0.1060 & $\begin{array}{c}\text { Overidentifing } \\
\text { Restrictions }\end{array}$ & 31.13059 & 0.2658 & $\begin{array}{l}\text { Overidentifying } \\
\text { Restrictions }\end{array}$ & 31.14405 & 0.2653 & $\begin{array}{c}\text { Overidentifing } \\
\text { Restrictions }\end{array}$ \\
\hline
\end{tabular}

. Source: Processed Data 
Market Share has a significant positive effect on CLR and X-Eff, which means that the higher market share, the more the company's competitiveness in winning the competition (CLR) and improve the performance of MSEs. The results of this regression are supported by research from Zainalabidin, Mason, dan Mudrajad [13]-[15]. According to estimates, the performance of MSEs (X-Eff) has a negative relationship to MS and CLR, which means that the higher the MSE performance, the higher the value added obtained by the company, thus encouraging companies outside the market to enter the market so that the market share is lower and the competition between companies in the market is getting tighter. market with production patterns that tend to be labor intensive [16]. Infrastructure, Agglomeration and Regulation have a significant positive effect on X-Eff, but bank credit is not significant for XEff with the argument that MSEs use their own capital in a relatively small amount.

\subsection{Economic Growth Equation Block}

Investment is one of the components that make up economic growth because investment has a broad multiplier effect because it not only encourages the production side, but also stimulates the consumption side of the community. Past investment (INVt-1) has a significant and positive influence in influencing the current investment value or capital accumulation, which means that for investors the decision to invest today is closely related to the success of previous investments, so that the investment made by the company contributes more and more. large to GDP. BPS data shows that the contribution of investment to the formation of GRDP in each region shows an increasing trend from year to year. In 2010, the average contribution of investment to GRDP was 29.32 percent, while in 2018 it increased to 32.74 percent, however, the performance of MSEs did not encourage investment in the regions because the greater the performance of MSEs, investment spending decreased because most of the investment directed to medium or large enterprises. One source of investment comes from public savings in the banking sector.

Table 5. Estimation Results of the Economic Growth Equation Block Using the GMM A-B Method

\begin{tabular}{|c|c|c|c|c|c|c|}
\hline \multirow[b]{2}{*}{ Variable } & \multicolumn{3}{|c|}{ Capital Accumulation } & \multicolumn{3}{|c|}{ Economic Growth } \\
\hline & $\begin{array}{c}\text { Estimated } \\
\text { Coefficients }\end{array}$ & P-Value & $\begin{array}{c}\text { Long-run } \\
\text { Multiplier }\end{array}$ & $\begin{array}{c}\text { Estimated } \\
\text { Coefficients }\end{array}$ & P-Value & $\begin{array}{c}\text { Long-run } \\
\text { Multiplier }\end{array}$ \\
\hline$I_{N} V_{t-1}$ & 0.4269095 & 0.000 & & & & \\
\hline GROWTH $_{t-1}$ & & & & 0.1606062 & 0.000 & \\
\hline$(\boldsymbol{X}-\overline{E F} F)_{\text {it }}$ & -0.018083 & 0.000 & 0,0318286 & 0.0112550 & 0.000 & 0,0134084 \\
\hline AGLO $_{\text {it }}$ & 0.4501079 & 0.000 & 0,7854045 & 0.1783689 & 0.026 & 0,2124972 \\
\hline INFRit & 0.0182407 & 0.004 & 0,0318286 & 0.0189353 & 0.000 & 0,0225583 \\
\hline NRit & 0.0384634 & 0.207 & 0,0671157 & 0.2562579 & 0.000 & 0,3052892 \\
\hline INV it $_{\text {it }}$ & & & & 0.0164253 & 0.287 & 0,0195680 \\
\hline GROWTH $_{\text {it }}$ & -0.961027 & 0.000 & $-1,676920$ & & & \\
\hline $\mathbf{S A V E}_{\text {it }}$ & 0.1836469 & 0.431 & 0,3204500 & & & \\
\hline Constanta & 21.77863 & 0.000 & & & & \\
\hline \multirow{2}{*}{$\begin{array}{l}\text { Arellano- } \\
\text { Bond } 22\end{array}$} & $\bar{Z}$ & P-Value & Keputusan & $\bar{Z}$ & P-Value & Keputusan \\
\hline & -0.80794 & 0.4191 & $\begin{array}{c}\text { No } \\
\text { Autocorrelation }\end{array}$ & 0,53036 & 0,5959 & $\begin{array}{c}\text { No } \\
\text { Autocorrelation }\end{array}$ \\
\hline \multirow[b]{2}{*}{ Sargan Test } & Chi (20) & P-Value & Keputusan & Chi (27) & P-Value & Keputusan \\
\hline & 23.57133 & 0.6540 & $\begin{array}{l}\text { Overidentifying } \\
\text { Restrictions }\end{array}$ & 30,32085 & 0,2999 & $\begin{array}{c}\text { Overidentifying } \\
\text { Restrictions }\end{array}$ \\
\hline
\end{tabular}

Source: Processed Data

The relationship between investment and saving in macro analysis shows that there is a Saving-Investment gap if the amount of investment distribution in Indonesia is also not evenly distributed, most of which are still concentrated on the island of Java, which is 58.26 percent 
and the rest is distributed in 18 provinces outside the country. Java Island. This condition is very different from the growth rate that occurs between provinces in Indonesia, in fact high economic growth actually occurs in Eastern Indonesia, but the investment level is relatively low, which means that high economic growth in Indonesia does not guarantee increased investment in the provinces in Indonesia. Indonesia, as an example of the highest economic growth in Indonesia in 2018 was achieved by the province of North Maluku with economic growth of 7.92 percent but the investment level was actually the lowest at 0.215 percent, while DKI Jakarta with growth of 6.17 percent was able to attract investment of 22.003 percent so that nationally this condition causes the effect of economic growth on investment to be negative. Economic growth that is not able to encourage investment in aggregate can also be proven by the relatively high Incremental Capital Output Ratio (ICOR) of Indonesia which shows that the level of efficiency is still low. ICOR is the ratio between investment in the past year and regional output growth (GRDP). ICOR can be a parameter that shows the level of investment efficiency in a country. The higher the ICOR value, the less efficient a country is for investment. ICOR is strongly influenced by the ease of doing business and the competitiveness of the labor market. A high ICOR value means that the use of incoming investment to stimulate economic growth is inefficient. From 2015 to 2018 Indonesia's ICOR ratio was still perched at a level above 6 (six). Compared to other ASEAN countries, Indonesia has the highest ICOR of 6.3 compared to Malaysia with an ICOR of 4.5 , the Philippines 3.7, Thailand 4.4, and Vietnam with an ICOR of 4.6.

The partial test results for the parameters in the structural equation of economic growth show that the coefficient on the lag of economic growth is positive and significant at the 1 percent real level, which means that every 1 percent increase in past economic growth will increase the current economic growth by 0.1606062 percent. The empirical results above indicate that there will be no convergence of growth between provinces in the Indonesian economy in the future, although provinces with low per capita income, namely Gorontalo and East Nusa Tenggara, tend to grow higher than provinces with per capita income. The higher ones are DKI Jakarta and East Kalimantan, so the convergence process takes a long time considering that the current income gap between rich and poor provinces is very wide. The MSEs performance variable which is a recursive variable from the regression results with the SCP approach $(\boldsymbol{X} \widehat{-\boldsymbol{E F} F})$ has a significant and positive correlation to growth. Statistically, it is found that every 1 percent increase in MSE performance will increase economic growth by 0.011255 percent in the short term and by 0.013408 percent in the long term. This condition is in accordance with the hypothesis that the performance of MSEs can be a driver of economic growth. Agglomeration on a national scale does not significantly affect economic growth but has a positive correlation, which means that the growth and development of industrial activities in an area has a positive correlation with economic growth. The results of this study estimate that infrastructure has a significant effect on growth with a positive correlation which means that it is in accordance with the hypothesis, while investment does not significantly affect economic growth but in a positive direction in accordance with the theory that investment is part of the formation of national income. However, it must still be noted that there are imbalances in infrastructure development and investment that are still focused on the provinces on the island of Java, so that it requires great efforts for the government to reduce development disparities between regions in Indonesia.

\subsection{Inclusive Growth Equation Block}


The results of processing using the GMM-AB method for the Inclusive Growth equation block consisting of 3 (three) structural equations, namely Income Distribution Inequality (INEQ), poverty level (POV) and employment absorption (EMPL) indicate that the four equations are based on the parameter estimation results with GMM Arellano-Bond has met the criteria for the consistency of the estimator. The structural equation for labor absorption and income distribution inequality shows that EMPLt-1 and INEQt-1 have negative coefficients which indicate that in the future there will be a convergent trend in labor absorption and inequality in income distribution between provinces in Indonesia. However, POVt-1 has a positive coefficient, which means that poverty convergence will occur in Indonesia in the future. The independent variable for access to education (EDU) is able to reduce inequality in income distribution, is able to increase employment, but has not been able to reduce the level of poverty, which means that access to education has not been optimally enjoyed by the poor. The average length of schooling which is still less than 9 years shows that Indonesia's Human Capital is still low, while access to health (HEALTH) which is proxied by the number of households using proper clean water sources (sanitation) has not been able to increase labor absorption and poverty despite having the potential to reduce income inequality but access to health between provinces still shows a very sharp difference.

Table 6. The Estimation Results Of The Inclusive Growth Equation

\begin{tabular}{|c|c|c|c|c|c|c|c|c|c|}
\hline \multirow{3}{*}{ Variable } & \multirow{2}{*}{\multicolumn{3}{|c|}{$\begin{array}{l}\text { Inequality of Income } \\
\text { Distribution (INEQ) }\end{array}$}} & \multirow{2}{*}{\multicolumn{3}{|c|}{ Employment (EMPL) }} & \multirow{2}{*}{\multicolumn{3}{|c|}{ Poverty (POV) }} \\
\hline & & & & & & & & & \\
\hline & $\begin{array}{c}\text { Estimate } \\
\text { Coefficient }\end{array}$ & P-Value & $\begin{array}{l}\text { Long run } \\
\text { Multiplier }\end{array}$ & $\begin{array}{c}\text { Estimate } \\
\text { Coefficient }\end{array}$ & P-Value & $\begin{array}{c}\text { Long run } \\
\text { Multiplier }\end{array}$ & $\begin{array}{c}\text { Estimate } \\
\text { Coefficient }\end{array}$ & P-Value & $\begin{array}{l}\text { Long run } \\
\text { Multiplier }\end{array}$ \\
\hline INEQt-1 & $-0,19992$ & 0.000 & & & & & & & \\
\hline EMPLt-1 & & & & -0.0595001 & 0.001 & & & & \\
\hline POVt-1 & & & & & & & 0.273558 & 0.000 & \\
\hline GROWTHt & $-0,00970$ & 0.000 & $-0,0080881$ & 0.0927095 & 0.000 & 0,087503 & 1.011307 & 0.000 & 1,392137 \\
\hline EDUt & $-0,14304$ & 0.000 & $-0,1192146$ & 4.931192 & 0.000 & 4,654262 & 5.915327 & 0.000 & 8,142875 \\
\hline HEALTHt & $-0,00014$ & 0.000 & $-0,0001197$ & -0.043159 & 0.000 & $-0,821549$ & 0.0151149 & 0.000 & 0,020806 \\
\hline INEQt & & & & 74.58305 & 0.000 & 7,039456 & -29.36468 & 0.000 & $-40,42260$ \\
\hline EMPLt & 0,060981 & 0.000 & 0,0508207 & & & & -2.168253 & 0.000 & $-2,98475$ \\
\hline POVt & $-0,00394$ & 0.501 & $-0,0032843$ & -0.0333825 & 0.001 & $-0,031504$ & & & \\
\hline Constata & $-4,12673$ & 0.000 & & 36.42795 & 0.000 & & 17.4134 & 0.000 & \\
\hline \multirow[b]{2}{*}{$\begin{array}{l}\text { Arellano- } \\
\text { Bond } m 2\end{array}$} & $Z$ & P-Value & Keputusan & $Z$ & P-Value & Keputusan & $Z$ & P-Value & Keputusan \\
\hline & -2.2881 & 0.0721 & $\begin{array}{c}\text { No } \\
\text { Autocorrelation }\end{array}$ & -1.755 & 0.0793 & $\begin{array}{c}\text { No } \\
\text { Autocorrelation } \\
\end{array}$ & 0.31675 & 0.7514 & $\begin{array}{c}\text { No } \\
\text { Autocorrelation }\end{array}$ \\
\hline \multirow{2}{*}{$\begin{array}{l}\text { Sargan } \\
\text { Test }\end{array}$} & Cli (27) & P-Value & Keputusan & Clii (27) & P-Value & Keputusan & Clii (27) & P-Value & Keputusan \\
\hline & 29.02124 & 0.3599 & $\begin{array}{c}\text { Overidentifing } \\
\text { Restrictions } \\
\end{array}$ & 30.35247 & 0.2986 & $\begin{array}{c}\text { Overidentifing } \\
\text { Restrictions }\end{array}$ & 29.76095 & 0.3250 & $\begin{array}{c}\text { Overidentifing } \\
\text { Restrictions }\end{array}$ \\
\hline
\end{tabular}

Source: Processed Data

The interesting findings in this study indicate that the performance of MSEs has a positive effect on economic growth and is able to increase employment (EMPL), reduce inequality in income distribution (INEQ). The same result is also obtained from the effect of economic growth which has a positive effect on employment and reduces income inequality. These results are also supported by previous studies, including Bruno, Ravallion and Squire; Dollar and Kraay; Son and Kakwani; and Adams [17]-[20]. However, economic growth supported by the performance of MSEs has not been able to reduce poverty (POV), which means that inclusive growth has not been realized in Indonesia.

\section{Conclusion and Policy Implications}




\subsection{Conclusion}

The purpose of this study is to estimate the performance of Micro and Small Enterprises (UMK) as a driver of economic growth capable of realizing inclusive growth, namely economic growth that can reduce poverty levels, income distribution inequality and increase employment. The conclusions from this research are as follows:

1. Micro and Small Enterprises (MSEs) in Indonesia have a market structure of monopolistic competition which is simultaneously related to the behavior of MSEs to win the competition and MSEs performance as measured by the ratio of added value to the value of their inputs which is influenced by inflation, provincial minimum wages and supported by regulations and benefit from the spillover effect of agglomeration and infrastructure, but the main problem of capital for MSEs has not been solved because bank credit has effect on MSEs performance.

2. The performance of MSEs, infrastructure, natural resources and investment is able to encourage economic growth, but on the other hand, economic growth and MSEs performance have not been able to increase investment due to inequality in the distribution of investment in Indonesia, which tends to be concentrated in Java and more investment in medium and big enterprises..

3. Economic growth supported by the performance of Micro and Small Enterprises (MSEs) is able to increase employment and reduce income distribution inequality, but has not been able to reduce poverty levels, besides that access to education and health has not been enjoyed by all people so that inclusive growth has not been realized in Indonesia.

\subsection{Policy Implications}

1. Empowerment of Micro and Small Enterprises is a necessity that must be improved by the government with various work programs that absorb a lot of manpower supported by adequate infrastructure development so that it has an impact on a more competitive market structure, highly competitive and improves performance efficiency so that in the end MSEs are able to drive economic growth and reduce poverty.

2. Stabilizing macroeconomic indicators, supported by the synergy of fiscal and monetary policies through various fiscal regulations and financial inclusion in favor of the poor so as to produce quality economic growth.

3. To support inclusive growth, the government needs to spend or invest more on education and health, spend more on priority areas such as infrastructure, social assistance, and increase state revenues so that state spending also increases.

\section{References}

[1] N. Kakwani dan E. Pernia, "What is Pro-poor Growth?," Asian Dev. Rev., vol. 18, no. 1, Jan 2000.

[2] M. Ravallion, “Are The World's Poorest Being Left Behind?,” 20791, 2014.

[3] S. Klasen, "Measuring and Monitoring Inclusive Growth: Multiple Definitions, Open Questions, and Some Constructive Proposals," 2010.

[4] R. Chambers, Poverty and Livelihood: Whose Reality Counts. England: Institute of Development Studies, 1995.

[5] M. J. Piore dan C. F. Sabel, The Second Industrial Divide. New York: Basic books, 
1984.

[6] J. Schumpeter, The Theory of Economic Development an Inquiry into Profits, Capital, Credit, Interest, and the Business Cycle. Harvard: Harvard University Press, 1934.

[7] M. Ayyagari, A. Demirguc-Kunt, dan V. Maksimovic, "Small vs. Young Firms across the World: Contribution to Employment, Job Creation, and Growth," 2011. doi: https://doi.org/10.1596/1813-9450-5631.

[8] J. Page dan M. Söderbom, "Is Small Beautiful? Small Enterprise, Aid and Employment in Africa," African Dev. Rev., vol. 27, no. S1, hlm. 44-55, 2015, doi: https://doi.org/10.1111/1467-8268.12138.

[9] T. Beck, A. D. Kunt, dan R. Levine, "SMEs, Growth, And Poverty: Cross-Country Evidence," J. Econ. Growth, vol. 10, hlm. 199-229, 2005.

[10] C. Djamhari, "Orientasi Pengembangan Agroindustri Skala Kecil dan Menengah; Rangkuman Pemikiran, Kementerian Koperasi dan UKM RI," J. Infokop, vol. 25, no. 20, hlm. 121-132, 2004.

[11] V. K. Tiwari $d k k$., "A Whole-Genome, radiation hybrid mapping resource of hexaploid wheat," Plant J., vol. 86, no. 2, hlm. 195-207, 2016, doi: https://doi.org/10.1111/tpj.13153.

[12] J. L. Gaffarrd, "Innovation, Competition, and Growth: Schumpeterian Ideas within a Hicksian Framework,” J. Evol. Econ., vol. 18, no. 3, hlm. 295-311, 2008.

[13] Z. Abidin, Manajemen Komunikasi: Filosofi, Konsep, dan Aplikasi. Bandung: Pustaka Setia, 2015.

[14] G. F. P. Mason, "Stare Decisis In The Court of Appeal," Mod. Law Rev., vol. 19, no. 2, hlm. 136-149, 1956.

[15] M. Kuncoro, Metode Riset Untuk Bisnis dan Ekonomi. Jakarta: Erlangga, 2007.

[16] D. R. Arini, "Analisis Kinerja Industri Kecil menengah (IKM)Batik Di Kota Pekalongan ( Pendekatan Strukture-Conduct-Performance)," Universitas Diponegoro, 2013.

[17] D. Dollar dan A. Kraay, "Growth is Good for the Poor," J. Econ. Growth, vol. 7, no. 3, hlm. 195-225, 2002.

[18] H. Son dan N. Kakwani, Economic Growth and Poverty Reduction: Initial Condition Matter. Brazil: International Poverty Centre, 2004.

[19] R. H. Adams, "Economic Growth, Inequality, and Poverty: Finding from a New Data Set," Washington DC, 2972, 2003. [Daring]. Tersedia pada: http://hdl.handle.net/10986/19109.

[20] M. Bruno, M. Ravallion, dan L. Squire, "Equity and Growth in Developing Countries: Old and New Perspectives on the Policy Issues," 1563, 1998. 